\title{
Tuning 1-D Pb(II) Coordination Polymers by Flexible and Semirigid Dicarboxylates: Synthesis, Structure and Properties
}

\author{
Guo-Cheng Liu, Zhi-Chao Guo, Xiu-Li Wang, Yun Qu, Song Yang, and Hong-Yan Lin \\ Department of Chemistry, Bohai University, Jinzhou, 121000, P. R. China \\ Reprint requests to Prof. Xiu-Li Wang. E-mail: wangxiuli@bhu.edu.cn
}

Z. Naturforsch. 2012, 67b, 185 -191; received February 14, 2012

Two new one-dimensional (1-D) $\mathrm{Pb}(\mathrm{II})$ coordination polymers, namely, $\left[\mathrm{Pb}(3-\right.$ pdip $\left.)\left(\mathrm{L}^{1}\right)\right] \cdot \mathrm{H}_{2} \mathrm{O}$ (1) and $\left[\mathrm{Pb}\left(3\right.\right.$-pdip) $\left.\left(\mathrm{L}^{2}\right)\right]\left(\right.$ 2) $\left[\mathrm{L}^{1} \mathrm{H}_{2}=1\right.$,6-hexanedioic acid, $\mathrm{L}^{2} \mathrm{H}_{2}=$ homophthalic acid, 3-pdip = 2-(3-pyridyl)imidazo[4,5-f]1,10-phenanthroline] have been obtained from hydrothermal reactions of $\mathrm{Pb}$ (II) nitrate with the phenanthroline derivative and the two dicarboxylic acids. Single-crystal X-ray diffraction analysis reveals that compound $\mathbf{1}$ is a staircase-like double-chain coordination polymer constructed from binuclear $\left[\mathrm{Pb}_{2} \mathrm{~N}_{4} \mathrm{O}_{8}\right]$ subunits and pairs of $\left[\mathrm{L}^{1}\right]^{2-}$ anions. Compound 2 is a linear coordination polymer connected via two $\mu_{2}-\eta^{2}: \eta^{1}$ carboxylate groups from $\left[\mathrm{L}^{2}\right]^{2-}$ anions. Furthermore, adjacent chains of $\mathbf{1}$ and $\mathbf{2}$ are extended into 3-D supramolecular networks by hydrogen bonds and $\pi-\pi$ stacking interactions. The organic carboxylic acids with different flexibility determine the structures of the coordination polymers. Moreover, the thermal stabilities and photoluminescence properties of compounds $\mathbf{1}$ and $\mathbf{2}$ were investigated.

Key words: Hydrothermal Syntheses, Crystal Structures, Lead Coordination Polymers, Photoluminescence

\section{Introduction}

The design and synthesis of lead(II) metal-organic coordination polymers have been greatly developed, not only because of their structural diversities, but also owing to their potential applications in gas storage and luminescence [1,2]. However, it is still a big challenge to predict the final structures of the desired crystalline products, since many factors such as organic ligands, solvent systems and temperature may have a great influence on the self-assembly process [3,4]. Recently, some 1,10-phenanthroline derivatives, such as 2-(4-hydroxylphenyl) imidazo[4,5-f]1,10-phenanthroline (HOIP), 2-(3-pyridyl)imidazo[4,5-f]1,10-phenanthroline (3-pdip) and 2-(4-pyridyl)imidazo[4,5-f]1,10-phenanthroline (4-pdip) with the common advantages of chelating and bridging $N$ donor ligands, have attracted great interest within coordination chemistry [1,2a]. In addition, careful selection of the organic ligands containing appropriate coordination sites linked by a proper spacer has been an effective way to obtain the target $\mathrm{Pb}$ (II) compounds [14]. As is known, multidentate organic dicarboxylate $O$ donor ligands can be divided into three types: flexible, semirigid and rigid ligands. The coordination behavior of flexible and rigid dicarboxylates in $\mathrm{Pb}(\mathrm{II})$ com- plexes was widely investigated by Ma, Batten, Wang, You, Casado, and our group [1, 2a, 3a, 5]. However, the chemistry of lead-organic coordination polymers based on semirigid dicarboxylates is relatively limited [6].

For this paper, we select the rigid phenanthroline derivative ligand 2-(3-pyridyl)imidazo[4,5-f]1,10phenanthroline (3-pdip) and two organic dicarboxylic acids (Scheme 1), flexible hexane diacid $\left(\mathrm{L}^{1} \mathrm{H}_{2}\right)$ and semirigid homophthalic acid $\left(\mathrm{L}^{2} \mathrm{H}_{2}\right)$ to investigate the influence of the flexibility of the organic carboxylic acids and the supramolecular recognition action of the $N$-donor co-ligand on the structure of the lead coordination polymers, based on the following considerations: (1) as a multidentate flexible $O$-donor ligand, $\mathrm{L}^{1} \mathrm{H}_{2}$ with multi $\mathrm{CH}_{2}$ groups for free twist may induce diverse metal-carboxylate coordination frameworks [1b,7]; (ii) as a multidentate semirigid $O$-donor ligand, $\mathrm{L}^{2} \mathrm{H}_{2}$ with a rigid spacer of a phenyl ring and only one freely rotating $\mathrm{CH}_{2}$ group may favor the formation of new metal-carboxylate subunits [8]; (iii) as a multifunctional $N$ donor ligand, 3-pdip not only possesses versatile potential coordination sites, but also has a large aromatic ring system and may provide potential supramolecular recognition sites for $\pi$ - $\pi$ stacking interactions, which may extend the metal-carboxylate subunits into high- 


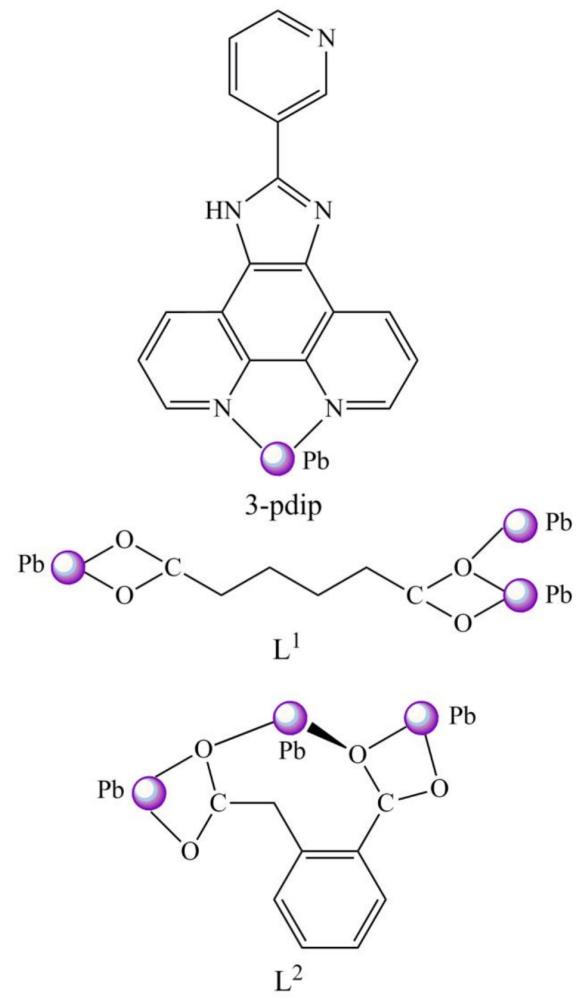

Scheme 1 (color online). The coordination modes of the dicarboxylate $\left(\left[\mathrm{L}^{1}\right]^{2-}\right.$ and $\left.\left[\mathrm{L}^{2}\right]^{2-}\right)$ and the 3-pdip ligands in the title compounds $\mathbf{1}$ and $\mathbf{2}$.

dimensional supramolecular networks [2a,9]. Moreover, the $\mathrm{H}$ atom of the imidazole group from 3-pdip and the $\mathrm{O}$ atoms of the carboxylate groups of $\left[\mathrm{L}^{1}\right]^{2-}$ and $\left[\mathrm{L}^{2}\right]^{2-}$ may provide the potential supramolecular recognition sites for hydrogen bonds interactions, which may stabilize the final frameworks [10].

In this paper, we report two 3-D supramolecular compounds derived from double chains and linear chains, respectively: $\left[\mathrm{Pb}(3-\mathrm{pdip})\left(\mathrm{L}^{1}\right)\right] \cdot \mathrm{H}_{2} \mathrm{O}(\mathbf{1})$ and $\left[\mathrm{Pb}(4-\mathrm{pdip})\left(\mathrm{L}^{2}\right)\right](2)$. The results of the investigation about the influence of the flexibility of dicarboxylates on the coordination frameworks is presented and discussed. Moreover, the thermal stabilities and photoluminescence properties of compounds $\mathbf{1}$ and $\mathbf{2}$ were studied.

\section{Results and Discussion}

Crystal and molecular structure of [Pb(3-pdip)$\left.\left(L^{1}\right)\right] \cdot \mathrm{H}_{2} \mathrm{O}(\mathbf{1})$

The single-crystal X-ray determination indicates that compound $\mathbf{1}$ is a $3-\mathrm{D}$ supramolecular framework

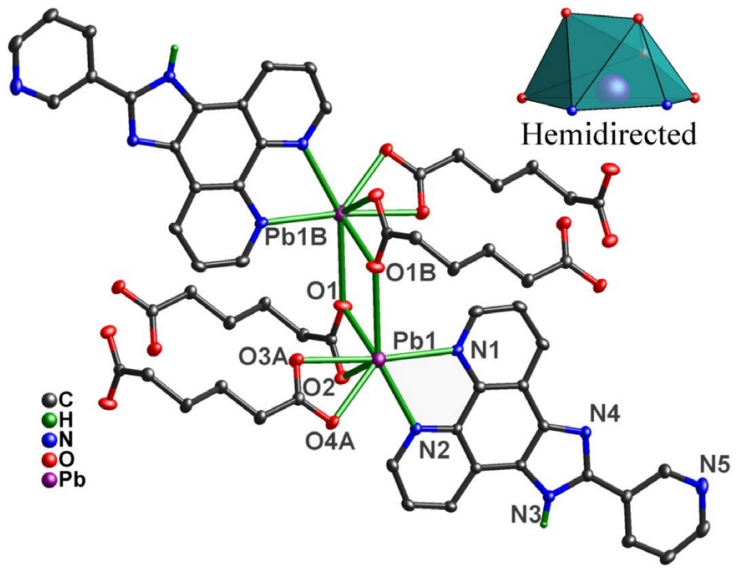

Fig. 1 (color online). The coordination environment of the $\mathrm{Pb}$ (II) atom in compound $\mathbf{1}$.

derived from staircase-like double chains extended by hydrogen bonds and $\pi$ - $\pi$ stacking interactions. In compound 1 , the lead atom is sevencoordinated by two oxygen atoms (O3A, O4A) of a chelating carboxylate group, three oxygen atoms $(\mathrm{O} 1, \mathrm{O} 2, \mathrm{O} 1 \mathrm{~B})$ of two chelating-bridging carboxylic groups from three different $\left[\mathrm{L}^{1}\right]^{2-}$ anions and two chelating nitrogen atoms (N1, N2) from one 3-pdip ligand showing a hemidirected coordination geometry (Fig. 1). The $\mathrm{Pb}-\mathrm{O}$ distances vary from $2.325(4)$ to $2.974(4) \AA$, and the $\mathrm{Pb}-$ $\mathrm{N}$ distances are 2.605(4) and 2.759(4) $\AA$, which are near to those reported for $\left[\mathrm{Pb}_{2}(\mathrm{~L})_{2}(1,4-\mathrm{bdc})_{2}\right]_{n}(1,4-$ bdc $=1$,4-benzenedicarboxylate and $\mathrm{L}=$ dipyrido[7,6$\left.a: 6^{\prime}, 7^{\prime}-c\right]$-3-chloropyrido[2,3-b]quinoxaline) [11]. The $\mathrm{N}-\mathrm{Pb}-\mathrm{N}$ angle is $60.89(12)^{\circ}$. The $\mathrm{O}-\mathrm{Pb}-\mathrm{O}$ and $\mathrm{N}-$ $\mathrm{Pb}-\mathrm{O}$ angles are in the range from $50.55(12)$ to $166.20(15)^{\circ}$ and $71.51(13)-154.53(13)^{\circ}$, respectively.

In compound $\mathbf{1}$, the two carboxylate groups of the $\left[\mathrm{L}^{1}\right]^{2-}$ anions exhibit asymmetric chelating-bridging coordination modes $\left(\mu_{2}-\eta^{2}: \eta^{1}\right)$. The two $\mu_{2}-\mathrm{O}$ atoms (O1 and O1B) from two carboxylate groups connect the adjacent $\mathrm{Pb}$ (II) atoms to form a bi-metallic $\left[\mathrm{Pb}_{2} \mathrm{~N}_{4} \mathrm{O}_{8}\right]$ subunit with a $\mathrm{Pb}(\mathrm{II}) \cdots \mathrm{Pb}$ (II) distance of 4.6351(14) $\AA$. The subunits are extended into a staircase-like double-chain coordination polymer through the pairs of $\left[\mathrm{L}^{1}\right]^{2-}$ anions (Fig. 2a), and the distance between the cores of the $\left[\mathrm{Pb}_{2} \mathrm{~N}_{4} \mathrm{O}_{8}\right]$ subunits is 9.267(4) $\AA$. In compound 1, intermolecular hydrogen bonds and $\pi-\pi$ stacking interactions play an important role in the construction of the supramolecular framework. As a 3-connected linker, the water molecule not only acts as an hydrogen bond acceptor, but also as a donor to link adjacent chains. 


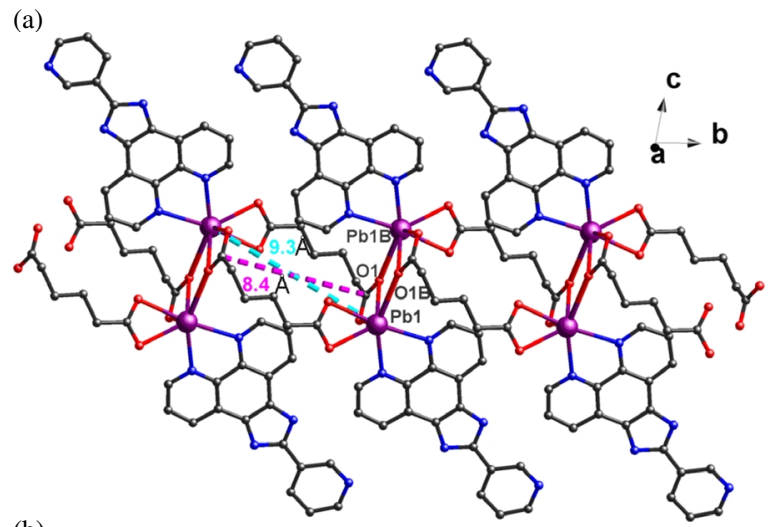

(b)

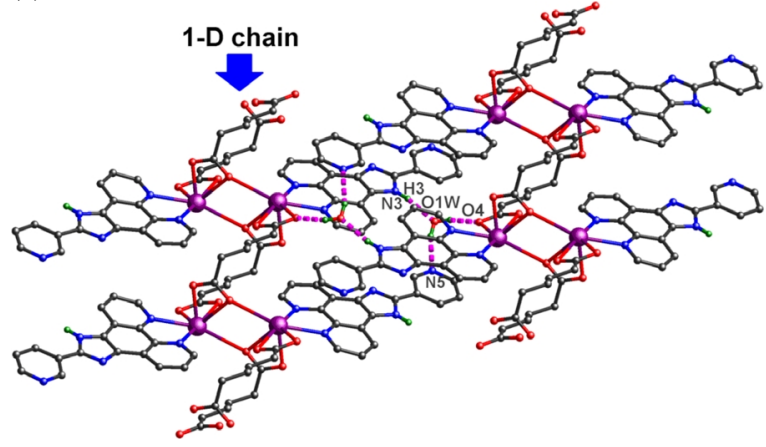

Fig. 2 (color online). (a) The 1-D coordination polymer extended through $\left[\mathrm{Pb}_{2} \mathrm{~N}_{4} \mathrm{O}_{8}\right]$ subunits and $\left[\mathrm{L}^{1}\right]^{2-}$ double linkers along the $b$ axis. (b) The 2-D supramolecular layer extended via $\mathrm{H}$ bonding interactions from the pyridine rings (N5), carboxylate oxygen (O4), imizole rings (N3) and lattice water molecules $(\mathrm{O} 1 \mathrm{~W})$.

The hydrogen bonding interactions between the atoms O1W, N3 and N5 stabilize the 1-D coordination polymer, and the hydrogen bonding interactions between $\mathrm{O} 1 \mathrm{~W}$ and $\mathrm{O} 4$ of the carboxylate groups link adjacent chains into a layer along the $a b$ plane $[\mathrm{O} 1 \mathrm{~W}-$ H1WA $\cdots$ N5C, 3.017(7) $\AA$, $159^{\circ}$ (C: $1-x, 2-y$, $-z)$. N3-H3 ‥ O1WE, 2.857(6) $\AA, 171^{\circ}$ (E: $1-x$,

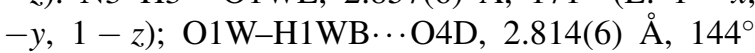
(D: $1-x, 1-y,-z$ ) (Fig. 2b)]. On the other hand, the $\pi$ - $\pi$-stacking interactions between the pyridine rings (containing $\mathrm{N} 2$ and N5) of 3pdip from different supramolecular layers connect the layers into a 3-D supramolecular architecture. $\mathrm{Cg}-\mathrm{Cg}$ (distance between ring centroids) is $3.587(4) \AA$, and the dihedral angle is $2.3(3)^{\circ}$.

Crystal and molecular structure of $\left[\mathrm{Pb}(3-p d i p)\left(L^{2}\right)\right]$ (2)

The X-ray diffraction study reveals that compound 2 is a 3-D supramolecular network constructed from

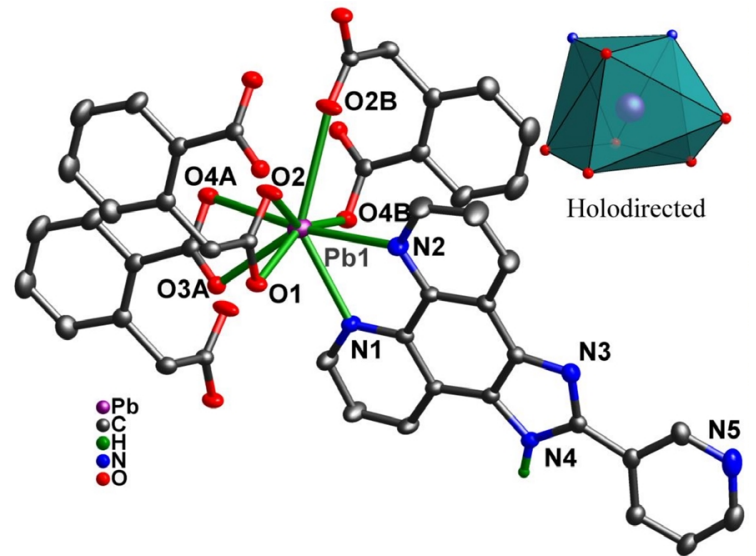

Fig. 3 (color online). The coordination environment of the $\mathrm{Pb}$ (II) atom in compound 2.

linear coordination polymer chains extended by hydrogen bonds and $\pi$ - $\pi$-stacking interactions. In compound 2 , each $\mathrm{Pb}(\mathrm{II})$ center is eight-coordinated by two chelating nitrogen atoms (N1 and N2) of the 3pdip ligand and six oxygen atoms of two cis chelatingbridging acetate groups $(\mathrm{O} 1, \mathrm{O} 2, \mathrm{O} 2 \mathrm{~B})$ and two trans chelating-bridging formylate groups $(\mathrm{O} 3 \mathrm{~A}, \mathrm{O} 4 \mathrm{~A}$, $\mathrm{O} 4 \mathrm{~B})$ from three different $\left[\mathrm{L}^{2}\right]^{2-}$ anions to form a holodirected coordination mode (Fig. 3). The $\mathrm{Pb}-\mathrm{N}$ distances are 2.545(2) and 2.609(2) $\AA$, while the $\mathrm{Pb}-$ O bond lengths range from $2.5442(2)$ to $2.901(3) \AA$ and are near the normal range [6]. The $\mathrm{N}-\mathrm{Pb}-\mathrm{N}$ angle is $63.50(7)^{\circ}$, while the $\mathrm{O}-\mathrm{Pb}-\mathrm{O}$ and $\mathrm{N}-\mathrm{Pb}-\mathrm{O}$ angles are in the range $48.41(5)-156.90(6)^{\circ}$ and $72.54(7)-$ $139.71(6)^{\circ}$, respectively.

It is notable that the two $\mu_{2}-\mathrm{O} 2$ atoms of two acetates with chelating-bridging $\mu_{2}-\eta^{2}: \eta^{1}$ coordination mode connect two $\mathrm{Pb}$ (II) centers, forming a binuclear $\left[\mathrm{Pb}_{2} \mathrm{~N}_{4} \mathrm{O}_{10}\right]$ secondary building unit (SBU) with a Pb1 $\cdots$ PbA distance of $4.556(3) \AA$. The two adjacent SBUs are further connected by two $\mu_{2}-\mathrm{O} 4$ atoms of two formylate groups with chelating-bridging $\mu_{2}$ $\eta^{2}: \eta^{1}$ coordination mode from $\left[\mathrm{L}^{2}\right]^{2-}$ anions to form a 1-D-[ $\left[\mathrm{PbO}_{2}\right]_{n}$-inorganic chain along the $a$ direction (Fig. 4a) [8d]. The distance PbA ...P PbB is 4.5279(2) $\AA$. The hydrogen bonding interactions between the N4 atoms of the imidazole groups and the $\mathrm{O} 1$ atoms of the acetate groups bridge the adjacent parallel chains to generate a layer along the $a b$ plane $[\mathrm{N}(4)-\mathrm{H}(4) \cdots \mathrm{O}(1)$, 2.803(3) $\left.\AA, 165(3)^{\circ}\right]$. The $\pi$ - $\pi$-stacking interactions between the pyridine rings (containing N1) of 3-pdip ligands from different parallel chains stabilize the layer (Fig. 4a). $\mathrm{Cg}-\mathrm{Cg}$ is $3.595(3) \AA$, and the dihe- 


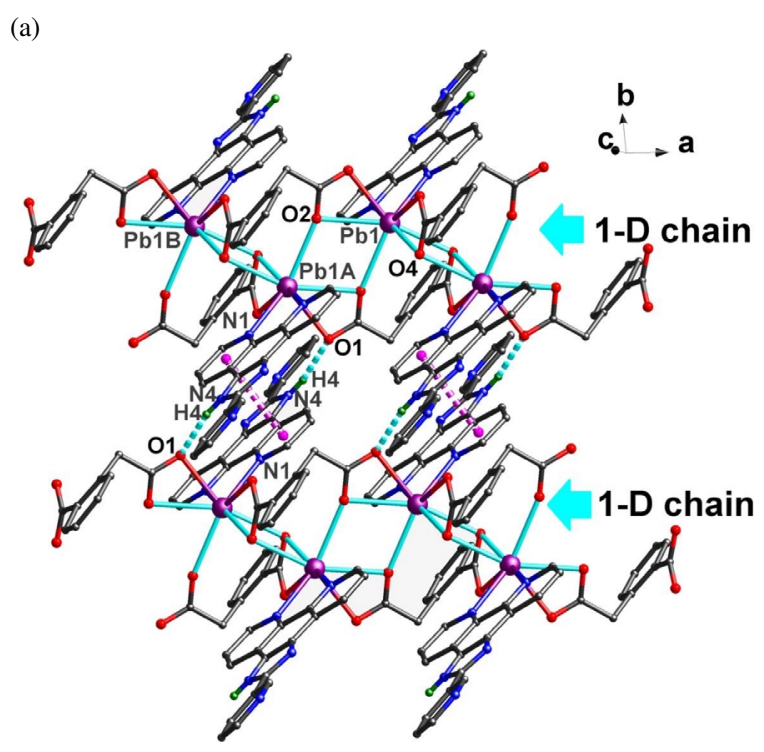

(b)

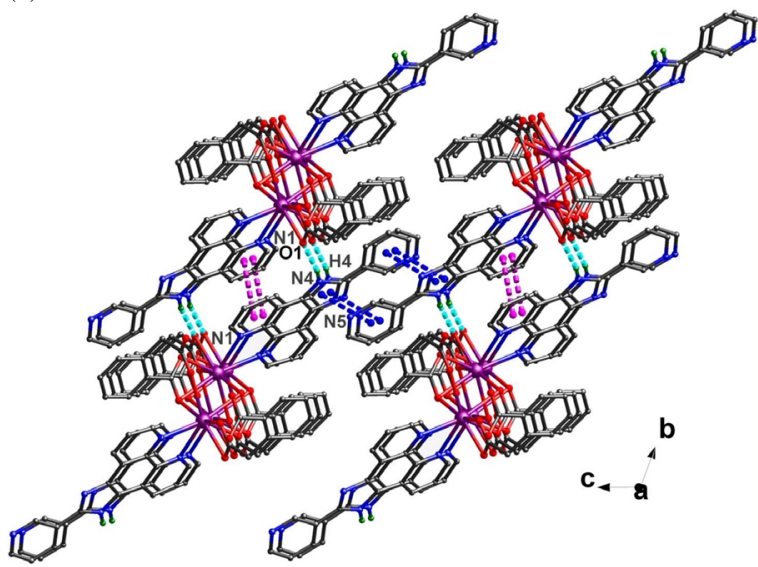

Fig. 4 (color online). The supramolecular layer derived from the 1-D coordination polymer possessing an inorganic $-\left[\mathrm{PbO}_{2}\right]_{n^{-}}$chain (sky blue). (b) The 3-D supramolecular framework connected through $\pi$ - $\pi$ stacking interactions between the pyridine rings (containing N5).

dral angle is $0^{\circ}$. Finally, the adjacent parallel layers are linked by $\pi$ - $\pi$-stacking interactions between the pyridine rings (containing N5) and the imidazole groups of the 3-pdip ligands from different parallel layers to form a 3-D supramolecular framework. $\mathrm{Cg}-$ $\mathrm{Cg}$ is $3.727(3) \AA$, and the dihedral angle is $10.61(1)^{\circ}$ (Fig. 4b).

From the structure description above, the carboxylate anions with different flexibility have a significant influence on the resulting structures of the title coordination polymers. The $\mathrm{Pb}$ (II) center is hemidirected in $\mathbf{1}$ and holodirected in $\mathbf{2}$, which is due to the differ- ent organic carboxylates in these two systems (Figs. 1 and 3 ). In compound $\mathbf{1}$, a flexible fatty dicarboxylate $\left(\left[\mathrm{L}^{1}\right]^{2-}\right)$ with a long distance between the two carboxylate groups was used. Therefore, a rectangular eighteen-membered ring was constructed by two $\left[\mathrm{L}^{1}\right]^{2-}$ anions and two lead atoms with a dimension of about $8.4 \times 9.3 \AA^{2}$ (Fig. 2a). Furthermore, a staircaselike metal-organic double chain is formed (Fig. 2a). Since a semirigid aromatic dicarboxylic anion ( $\left[\mathrm{L}^{2}\right]^{2-}$ ) is used in $\mathbf{2}$, the shorter distance of the two carboxylic groups and the steric effect of $\mathrm{L}^{2}$ make the distance between the $\mathrm{Pb}$ atoms shorter. Thus, a linear $-\left[\mathrm{PbO}_{2}\right]_{n}$ inorganic chain was obtained (Fig. 4a). The 3-pdip ligands in compounds $\mathbf{1}$ and $\mathbf{2}$ show the same chelating coordination modes only acting as terminal groups, and the $\mathrm{N}$ atoms from the imidazole and 3-pryridine groups can not coordinate to the $\mathrm{Pb}$ atom to extend the double chain, which may have steric reasons. However, these uncoordinated $\mathrm{N}$ atoms play an important role in extending the $\mathrm{Pb}$ carboxylate chains into highdimensional supramolecular networks through hydrogen bonds.

\section{IR spectra}

The main features in the IR spectra of $\mathbf{1}$ and $\mathbf{2}$ are due to the carboxylate, and $\mathrm{CH}_{2}$ groups, water molecules and $\mathrm{N}$-containing ligands. No strong absorption peaks around $1700 \mathrm{~cm}^{-1}$ for $-\mathrm{COOH}$ are observed, indicating that all carboxyl groups of the organic moieties are deprotonated [12]. The bands at about 800 and $705 \mathrm{~cm}^{-1}$ may be attributed to the $v(\mathrm{C}$ $\mathrm{N})$ stretching of the $\mathrm{N}$-heterocyclic rings of the 3pdip ligands, and the weak absorption peaks of the $\mathrm{CH}_{2}$ - groups appeared at around 2945 and $2932 \mathrm{~cm}^{-1}$ in compounds $\mathbf{1}$ and $\mathbf{2}$, respectively [13]. For compound 1 , the strong broad band at around $3400 \mathrm{~cm}^{-1}$ was assigned to the $v(\mathrm{O}-\mathrm{H})$ vibrations of water molecules [14]. The vibrations of the carboxylate groups appeared at 1677 and $1552 \mathrm{~cm}^{-1}$ (for 1), and at 1610 and $1528 \mathrm{~cm}^{-1}$ (for 2) [15].

\section{Thermal properties}

To investigate the thermal stabilities of the title compounds, their decomposition behavior was studied by thermogravimetric analyses (TGA) with a heating rate of $10{ }^{\circ} \mathrm{C} \mathrm{min}-1$ in the temperature range of 30 to $800{ }^{\circ} \mathrm{C}$ (Fig. 5). The weight loss of 1 corresponding to the release of water molecules occurred at about $200{ }^{\circ} \mathrm{C}$, showing good stability due to the ex- 


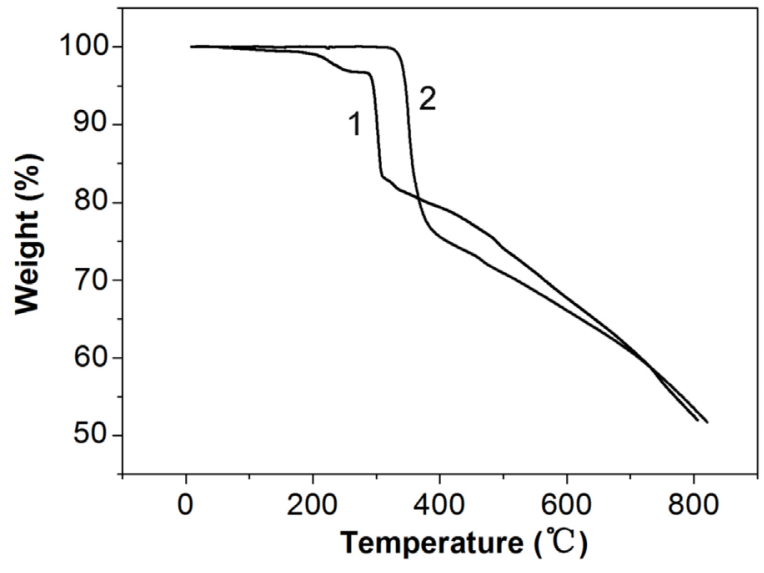

Fig. 5. Thermogravimetric analysis of $\mathbf{1}$ and $\mathbf{2}$.

istence of hydrogen bonding interactions between the water molecules and the coordination framework (observed $2.7 \%$, calcd. $2.7 \%$ ). The significant weight loss at $300{ }^{\circ} \mathrm{C}$ can be attributed to the decomposition of the framework. Comparing with $\mathbf{1}$, compound $\mathbf{2}$ is slightly more stable up to $330{ }^{\circ} \mathrm{C}$, where the collapse of the framework starts a significant weight loss.

\section{Photoluminescence properties}

To study the fluorescence properties of the title compounds, the emission spectra of $\mathbf{1}$ and $\mathbf{2}$ in the solid state at ambient temperature were measured (Fig. 6). Compound 1 exhibits green photoluminescence with an emission maximum at $c a .395 \mathrm{~nm}$ upon excitation at $330 \mathrm{~nm}$, while the emission maximum of $\mathbf{2}$ is at about $545 \mathrm{~nm}\left(\lambda_{\mathrm{ex}}=470 \mathrm{~nm}\right)$. Compared with the emission of 3-pdip $\left(\lambda_{\mathrm{ex}}=260 \mathrm{~nm}, \lambda_{\mathrm{em}}=422 \mathrm{~nm}\right)$ [9a],

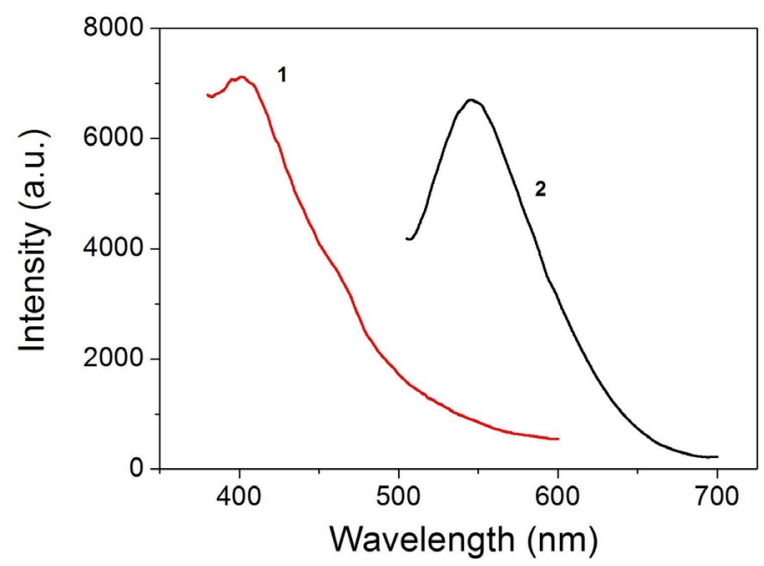

Fig. 6 (color online). Fluorescence spectra of $\mathbf{1}$ and $\mathbf{2}$ in the solid state at room temperature. a blue shift of $c a .25 \mathrm{~nm}$ (for 1) and a red shift of ca. $120 \mathrm{~nm}$ (for 2) have been observed. Compared with the $\pi^{*} \rightarrow \pi$ transitions of the 3-pdip ligand, the carboxylate ligands show very weak $\pi^{*} \rightarrow n$ transitions which contribute little to the photoluminescence of the title compounds [2a]. Therefore, the solid state photoluminescence of compounds $\mathbf{1}$ and $\mathbf{2}$ may be attributed to metal-to-ligand and ligand-to-metal charge-transfer transitions, respectively [2a]. The different emission bands of $\mathbf{1}$ and $\mathbf{2}$ may be due to the different structures and organic carboxylates used in this work [16].

\section{Conclusion}

In summary, we have synthesized two new $\mathrm{Pb}$ (II) coordination polymers constructed from one phenanthroline derivative and two organic dicarboxylic acids. Compounds $\mathbf{1}$ and $\mathbf{2}$ exhibit a staircase-like doublechain and a linear single-chain architecture, respectively, further extended into 3-D supramolecular frameworks by hydrogen bonds and $\pi$ - $\pi$-stacking interactions. The organic carboxylic acids with different flexibility determine the structure of the 1-D $\mathrm{Pb}$ (II)carboxylate coordination polymers. Hydrogen bonds and $\pi$ - $\pi$-stacking interactions have a great influence on the final supramolecular frameworks. Moreover, the title compounds with the blue/green fluorescence properties and excellent thermal stability may be used as luminescent materials.

\section{Experimental Section}

Materials and methods

3-pdip was synthesized by the method given in [17]. All other reagents employed were commercially available and used as received without further purification. FT-IR spectra (KBr pellets) were taken on a Magna FTIR 560 spectrometer, and the elemental analyses (C, $\mathrm{H}$, and $\mathrm{N}$ ) were carried out on a Perkin-Elmer 240C elemental analyzer. The luminescence spectra for the samples were measured on a Hitachi F-4500 fluorescence spectrophotometer, and thermogravimetric analysis was carried out with a Pyris Diamond TG-DTA instrument.

\section{Synthesis of $\left[\mathrm{Pb}(3-p d i p)\left(L_{1}\right)\right] \cdot \mathrm{H}_{2} \mathrm{O}(\mathbf{1})$}

A mixture of $\mathrm{Pb}\left(\mathrm{NO}_{3}\right)_{2} \quad(0.1 \mathrm{mmol}), \quad \mathrm{L}^{1} \mathrm{H}_{2}$ (0.1 mmol), 3-pdip (0.1 mmol), $\mathrm{H}_{2} \mathrm{O}(14 \mathrm{~mL})$, and $\mathrm{NaOH}(0.2 \mathrm{mmol})$ was stirred for $30 \mathrm{~min}$ in air, then 
Table 1. Crystal data and numbers pertinent to data collection and structure refinement of compounds $\mathbf{1}$ and $\mathbf{2}$.

\begin{tabular}{|c|c|c|}
\hline & $\mathbf{1}$ & 2 \\
\hline Formula & $\mathrm{C}_{24} \mathrm{H}_{21} \mathrm{PbN}_{5} \mathrm{O}_{5}$ & $\mathrm{C}_{27} \mathrm{H}_{16} \mathrm{PbN}_{5} \mathrm{O}_{4}$ \\
\hline $\mathrm{Mr}$ & 666.65 & 681.65 \\
\hline$T, \mathrm{~K}$ & 293(2) & 293(2) \\
\hline Crystal system & triclinic & triclinic \\
\hline Space group & $P \overline{1}$ & $P \overline{1}$ \\
\hline$a, \AA$ & $7.479(5)$ & $7.662(5)$ \\
\hline$b, \AA$ & $9.127(5)$ & $11.935(5)$ \\
\hline$c, \AA$ & $16.535(5)$ & $13.404(5)$ \\
\hline$\alpha, \operatorname{deg}$ & $78.706(5)$ & $108.998(5)$ \\
\hline$\beta$, deg & $88.849(5)$ & $92.692(5)$ \\
\hline$\gamma$, deg & $83.015(5)$ & $101.757(5)$ \\
\hline$V, \AA^{3}$ & $1098.6(10)$ & $1126.1(10)$ \\
\hline$Z$ & 2 & 2 \\
\hline$D_{\text {calcd }}, \mathrm{g} \mathrm{cm}^{-3}$ & 2.02 & 2.01 \\
\hline$\mu\left(\mathrm{Mo} K_{\alpha}\right), \mathrm{mm}^{-1}$ & 7.7 & 7.5 \\
\hline$F(000), \mathrm{e}$ & 603 & 654 \\
\hline$\theta_{\max }, \operatorname{deg}$ & 27.72 & 28.25 \\
\hline Refl. measured / unique & 17882 / 5162 & $19200 / 5567$ \\
\hline$R_{\text {int }}$ & 0.0356 & 0.0231 \\
\hline Ref. parameters / data & $316 / 5101$ & $338 / 5530$ \\
\hline$R 1^{a}[I \geq 2 \sigma(I)]$ & 0.0303 & 0.0157 \\
\hline$w R 2^{\mathrm{b}}$ (all data) & 0.1016 & 0.0400 \\
\hline $\mathrm{GOF}^{\mathrm{c}}$ & 1.122 & 1.044 \\
\hline$\Delta \rho_{\max / \min }, \mathrm{e} \AA^{-3}$ & $1.7 /-1.8$ & $0.5 /-0.7$ \\
\hline
\end{tabular}

transferred and sealed in a $25 \mathrm{~mL}$ Teflon reactor, which was heated at $170{ }^{\circ} \mathrm{C}$ for $3 \mathrm{~d}$, leading to the formation of yellow block-shaped crystals of 1 ( $\sim 38 \%$ yield based on $\mathrm{Pb}$ ). - Anal. for $\mathrm{C}_{24} \mathrm{H}_{21} \mathrm{PbN}_{5} \mathrm{O}_{5}$ : calcd. C 43.24, H 3.18, N 10.51; found C 43.29, H 3.22, $\mathrm{N} 10.47 \%$. - IR $\left(\mathrm{KBr}, \mathrm{cm}^{-1}\right): v=3400(\mathrm{w}), 2945(\mathrm{w})$, 1677(m), 1552(s), 1404 s, 1309(s), 1070(m), 821(m), 705(s).

\section{Synthesis of $\left[\mathrm{Pb}(3-p d i p)\left(L_{2}\right)\right](2)$}

The synthetic procedure for $\mathbf{2}$ is the same as that for 1 except that $\mathrm{L}^{2} \mathrm{H}_{2}(0.1 \mathrm{mmol})$ was used instead of $\mathrm{L}^{1} \mathrm{H}_{2}$. Yellow block-shaped crystals of $\mathbf{2}$ were obtained $(\sim 34 \%$ yield based on $\mathrm{Pb})$. - Anal. for $\mathrm{C}_{27} \mathrm{H}_{16} \mathrm{PbN}_{5} \mathrm{O}_{4}$ : calcd. C 47.50, H 2.37, N 10.26; found C 47.48, H 2.35, N 10.22\%. - IR $\left(\mathrm{KBr}, \mathrm{cm}^{-1}\right)$ : $v=2932(\mathrm{w}), 1610(\mathrm{~m}), 1528(\mathrm{~s}), 1470(\mathrm{~s}), 1430(\mathrm{w})$, 1366(m), 802(s).

\section{$X$-Ray structure determinations}

Crystallographic data for the title compounds were collected on a Bruker Smart 1000 CCD diffractometer
Table 2. Selected bond lengths $(\AA)$ and angles (deg) for compounds $\mathbf{1}$ and $\mathbf{2}$.

\begin{tabular}{|c|c|c|c|}
\hline \multicolumn{4}{|c|}{1} \\
\hline $\mathrm{Pb}(1)-\mathrm{N}(1)$ & $2.759(4)$ & $\mathrm{Pb}(1)-\mathrm{N}(2)$ & $2.605(4)$ \\
\hline $\mathrm{Pb}(1)-\mathrm{O}(1)$ & $2.586(4)$ & $\mathrm{Pb}(1)-\mathrm{O}(2)$ & $2.325(4)$ \\
\hline $\mathrm{Pb}(1)-\mathrm{O}(3)^{\mathrm{A}}$ & $2.584(4)$ & $\mathrm{Pb}(1)-\mathrm{O}(4)^{\mathrm{A}}$ & $2.582(4)$ \\
\hline $\mathrm{Pb}(1)-\mathrm{O}(1)^{\mathrm{B}}$ & $2.974(4)$ & $\mathrm{O}(2)-\mathrm{Pb}(1)-\mathrm{O}(4)^{\mathrm{A}}$ & $85.16(14)$ \\
\hline $\mathrm{O}(3)^{\mathrm{A}}-\mathrm{Pb}(1)-\mathrm{N}(2)$ & $121.57(13)$ & $\mathrm{O}(2)-\mathrm{Pb}(1)-\mathrm{O}(3)^{\mathrm{A}}$ & $78.14(15)$ \\
\hline $\mathrm{O}(1)-\mathrm{Pb}(1)-\mathrm{N}(2)$ & $115.81(14)$ & $\mathrm{O}(4)^{\mathrm{A}}-\mathrm{Pb}(1)-\mathrm{O}(3)^{\mathrm{A}}$ & $50.55(12)$ \\
\hline $\mathrm{O}(2)-\mathrm{Pb}(1)-\mathrm{N}(1)$ & $90.72(14)$ & $\mathrm{O}(2)-\mathrm{Pb}(1)-\mathrm{O}(1)$ & $52.77(13)$ \\
\hline $\mathrm{O}(4)^{\mathrm{A}}-\mathrm{Pb}(1)-\mathrm{N}(1)$ & $137.41(12)$ & $\mathrm{O}(4)^{\mathrm{A}}-\mathrm{Pb}(1)-\mathrm{O}(1)$ & $120.75(13)$ \\
\hline $\mathrm{O}(3)^{\mathrm{A}}-\mathrm{Pb}(1)-\mathrm{N}(1)$ & $166.20(15)$ & $\mathrm{O}(3)^{\mathrm{A}}-\mathrm{Pb}(1)-\mathrm{O}(1)$ & $78.49(14)$ \\
\hline $\mathrm{O}(1)-\mathrm{Pb}(1)-\mathrm{N}(1)$ & $88.31(14)$ & $\mathrm{O}(2)-\mathrm{Pb}(1)-\mathrm{N}(2)$ & 71.51(13) \\
\hline $\mathrm{N}(2)-\mathrm{Pb}(1)-\mathrm{N}(1)$ & $60.89(12)$ & $\mathrm{O}(4)^{\mathrm{A}}-\mathrm{Pb}(1)-\mathrm{N}(2)$ & $77.76(12)$ \\
\hline $\mathrm{O}(2)-\mathrm{Pb}(1)-\mathrm{O}(1)^{\mathrm{B}}$ & $119.54(12)$ & $\mathrm{O}(1)-\mathrm{Pb}(1)-\mathrm{O}(1)^{\mathrm{B}}$ & $67.25(14)$ \\
\hline $\mathrm{O}(4)^{\mathrm{A}}-\mathrm{Pb}(1)-\mathrm{O}(1)^{\mathrm{B}}$ & $123.88(12)$ & $\mathrm{N}(2)-\mathrm{Pb}(1)-\mathrm{O}(1)^{\mathrm{B}}$ & $154.53(13)$ \\
\hline $\mathrm{O}(3)^{\mathrm{A}}-\mathrm{Pb}(1)-\mathrm{O}(1)^{\mathrm{B}}$ & $83.86(14)$ & $\mathrm{N}(1)-\mathrm{Pb}(1)-\mathrm{O}(1)^{\mathrm{B}}$ & $94.80(13)$ \\
\hline \multicolumn{4}{|c|}{ Symmetry code: ${ }^{\mathrm{A}} 2-x,-y, 1-z ;{ }^{\mathrm{B}} 2-x, 1-y, 1-z$} \\
\hline \\
\hline$\overline{\mathrm{Pb}(1)-\mathrm{N}(1)}$ & $2.545(2)$ & $\mathrm{Pb}(1)-\mathrm{N}(2)$ & $2.609(2)$ \\
\hline $\mathrm{Pb}(1)-\mathrm{O}(3)^{\mathrm{A}}$ & $2.5442(2)$ & $\mathrm{Pb}(1)-\mathrm{O}(4)^{\mathrm{B}}$ & $2.668(2)$ \\
\hline $\mathrm{Pb}(1)-\mathrm{O}(1)$ & $2.5735(2)$ & $\mathrm{Pb}(1)-\mathrm{O}(2)$ & $2.759(2)$ \\
\hline $\mathrm{Pb}(1)-\mathrm{O}(4)^{\mathrm{A}}$ & $2.901(3)$ & $\mathrm{Pb}(1)-\mathrm{O}(2)^{\mathrm{B}}$ & $2.868(2)$ \\
\hline $\mathrm{N}(1)-\mathrm{Pb}(1)-\mathrm{O}(3)^{\mathrm{A}}$ & $79.49(6)$ & $\mathrm{O}(1)-\mathrm{Pb}(1)-\mathrm{O}(4)^{\mathrm{B}}$ & $154.15(6)$ \\
\hline $\mathrm{N}(1)-\mathrm{Pb}(1)-\mathrm{O}(1)$ & $84.05(7)$ & $\mathrm{N}(2)-\mathrm{Pb}(1)-\mathrm{O}(4)^{\mathrm{B}}$ & $95.67(8)$ \\
\hline $\mathrm{O}(3)^{\mathrm{A}}-\mathrm{Pb}(1)-\mathrm{O}(1)$ & $77.45(6)$ & $\mathrm{N}(1)-\mathrm{Pb}(1)-\mathrm{O}(2)$ & $123.46(7)$ \\
\hline $\mathrm{N}(1)-\mathrm{Pb}(1)-\mathrm{N}(2)$ & $63.50(7)$ & $\mathrm{O}(3)^{\mathrm{A}}-\mathrm{Pb}(1)-\mathrm{O}(2)$ & $110.72(7)$ \\
\hline $\mathrm{O}(3)^{\mathrm{A}}-\mathrm{Pb}(1)-\mathrm{N}(2)$ & $139.71(6)$ & $\mathrm{O}(1)-\mathrm{Pb}(1)-\mathrm{O}(2)$ & $48.41(5)$ \\
\hline $\mathrm{O}(1)-\mathrm{Pb}(1)-\mathrm{N}(2)$ & $83.16(7)$ & $\mathrm{N}(2)-\mathrm{Pb}(1)-\mathrm{O}(2)$ & $79.88(8)$ \\
\hline $\mathrm{N}(1)-\mathrm{Pb}(1)-\mathrm{O}(4)^{\mathrm{B}}$ & $72.54(7)$ & $\mathrm{O}(4)^{\mathrm{B}}-\mathrm{Pb}(1)-\mathrm{O}(2)$ & $156.90(6)$ \\
\hline $\mathrm{O}(3)^{\mathrm{A}}-\mathrm{Pb}(1)-\mathrm{O}(4)^{\mathrm{B}}$ & $87.42(7)$ & & \\
\hline \multicolumn{4}{|c|}{ Symmetry code: ${ }^{\mathrm{A}} 1+x, y, z ;^{\mathrm{B}} 1-x,-y, 1-z}$. \\
\hline
\end{tabular}

with $\operatorname{Mo} K_{\alpha}$ radiation $(\lambda=0.71073 \AA)$ in the $\omega$ scan mode. The structures were solved by Direct Methods using the SHELXS program of the SHELXTL package and refined by full-matrix least-squares methods with SHELXL $[18,19]$. All non-hydrogen atoms were refined anisotropically, and all hydrogen atoms were placed in geometrically idealized positions and refined isotropically. The details of crystallographic information for compounds $\mathbf{1}$ and $\mathbf{2}$ are summarized in Table 1 . Selected bond lengths and angles of the title compounds are listed in Table 2.

CCDC 866643 (1) and 866644 (2) contain the supplementary crystallographic data for this paper. These data can be obtained free of charge from The Cambridge Crystallographic Data Centre via www.ccdc.cam.ac.uk/data_request/cif.

\section{Acknowledgement}

This work was supported by the National Natural Science Foundation of China (no. 21171025) and the Natural Science Foundation of Liaoning Province (no. 201102003 and 2009402007). 
[1] a) J. Yang, G. D. Li, J. J. Cao, Q. Yue, G. H. Li, J. S. Chen, Chem. Eur. J. 2007, 13, 3248 -3261; b) J. Yang, J. F. Ma, Y. Y. Liu, J. C. Ma, S. R. Batten, Inorg. Chem. 2007, 46, 6542-6555; c) J. Yang, J. F. Ma, Y. Y. Liu, J. C. Ma, S.R. Batten, Cryst. Growth Des. 2009, 9, $1894-1911$.

[2] a) X. L. Wang, Y. Q. Chen, Q. Gao, H. Y. Lin, G. C. Liu, J.X. Zhang, A. X. Tian, Cryst. Growth Des. 2010, 10, 2174-2184; b) X. Y. Wang, J. Guo, H. L. Wang, Q. W. Wang, Z. Naturforsch. 2011, 66b, 647-650; c) Z.L. Xu, Y. He, H. L. Wang, Z. Naturforsch. 2011, 66b, 899-904; d) X. Y. Wang, S. Ma, T. Li, N. S. Weng, Z. Naturforsch. 2011, 66b, $103-106$; e) X. L. Wang, Q. Gao, Y. Q. Chen, G. C. Liu, A. X. Tian, Z. H. Kang, Z. Anorg. Allg. Chem. 2011, 637, $142-147$.

[3] a) X.X. Xu, X. X. Liu, X. G. Sang, E. B. Wang, J. Coord. Chem. 2010, 63, 3060-3070; b) K. Chen, Z. G. Sun, Y. Y. Zhu, Z. M. Liu, F. Tong, D. P. Dong, J. Li, C. Q. Jiao, C. Li, C.L. Wang, Cryst. Growth Des. 2011, 11, 4623-4631; c) S. C. Chen, Z. H. Zhang, Y. S. Zhou, W. Y. Zhou, Y.Z. Li, M. Y. He, Q. Chen, M. Du, Cryst. Growth Des. 2011, 11, 4190-4197

[4] a) Z. Wei, J. H. Yang, V. D. Vreshch, A. V. Zabula, A. S. Filatov, E. V. Dikarev, Inorg. Chem. 2011, 50, 7295 7300; b) B. Ding, Y. Y. Liu, X. X. Wu, X. J. Zhao, G. X. Du, E. C. Yang, X. G. Wang, Cryst. Growth Des. 2009, 9, 4176-4180.

[5] a) F. J. M. Casado, M. R. Riesco, I. Silva, M. I. R. Yeílamos, A. Labrador, J. A. R. Cheda, Cryst. Growth Des. 2011, 11, 759-767; b) X. Q. Liang, D. P. Li, X. H. Zhou, Y. Sui, Y.Z. Li, J.L. Zuo, X.Z. You, Cryst. Growth Des. 2009, 9, $4872-4883$.

[6] M. L. Hu, A. Morsali, L. Aboutorabi, Coord. Chem. Rev. 2011, 255, 2821-2859.

[7] a) X.L. Wang, H.L. Hu, A.X. Tian, H. Y. Lin, J. Li, Inorg. Chem. 2010, 49, 10299 - 10306; b) X. Z. Song, S. Y. Song, C. Qin, S. Q. Su, S. N. Zhao, M. Zhu, Z. M. Hao, H. J. Zhang, Cryst. Growth Des. 2012, 12, $253-263$; c) D. Sun, H. R. Xu, C. F. Yang, Z. H. Wei, N. Zhang, R.B. Huang, L.S. Zheng, Cryst. Growth Des. 2010, 10, 4642 -4649; d) A. Banisafar, D. P. Martin, J.S. Lucas, R. L. LaDuca, Cryst. Growth Des. 2011, 11, 1651-1661.

[8] a) G.Z. Liu, L. Y. Xin, L. Y. Wang, CrystEngComm
2011, 13, 3013-3020; b) A. D. Burrows, R.W. Harrington, M. F. Mahon, S. J. Teat, Eur. J. Inorg. Chem. 2003, 766-776; c) A. D. Burrows, R. W. Harrington, M. F. Mahon, S. J. Teat, Cryst. Growth Des. 2004, 4, 813 -822; d) X. D. Zhu, X. J. Li, Q. Y. Liu, J. Lü, Z. G. Guo, J.R. He,Y. F. Li, R. Cao, J. Solid State Chem. 2007, 180, 2386-2392.

[9] a) X. L. Wang, G. C. Liu, J.X. Zhang, Y. Q. Cheng, H. Y. Lin, W. Y. Zheng, Dalton Trans 2009, $7347-$ 7349; b) X. L. Wang, J. X. Zhang, G. C. Liu, H. Y. Lin, J. Solid State Chem 2011, 184, 280-288

[10] X. L. Wang, Y. Q. Chen, G. C. Liu, J. X. Zhang, H. Y. Lin, B. K. Chen, Inorg. Chim. Acta 2010, 363, $773-$ 778.

[11] X. Y. Wang, Y. He, L. N. Zhao, Z. G. Kong, Inorg. Chem. Commun 2011, 14, 1186-1189

[12] a) X. L. Wang, G. C. Liu, H. Y. Lin, Y. F. Bi, J. Coord. Chem. 2007, 4, 423-430; b) X. L. Wang, G. C. Liu, B. K. Chen, Y. F. Bi, H. Y. Lin, J. Coord. Chem. 2008, 61, 1635-1644.

[13] a) G. C. Liu, S. Yang, X. L. Wang, H. Y. Lin, A. X. Tian, J. W. Zhang, Rus. J. Coord. Chem. 2012, 38, 55-60; b) G. C. Liu, S. Yang, X. L. Wang, Y. F. Wang, H. Y. Lin, J. X. Zhang, Rus. J. Inorg. Chem. 2011, 56, $1918-$ 1923.

[14] L. J. Bellamy, The Infrared Spectra of Complex Molecules, Wiley, New York, 1958.

[15] K. Nakamoto, Infrared Spectra and Raman Spectra of Inorganic and Coordination Compound, Wiley, New York, 1986.

[16] V. Amendola, L. Fabbrizzi, F. Foti, M. Licchelli, C. Mangano, P. Pallavicini, A. Poggi, D. Sacchi, A. Taglietti, Coord. Chem. Rev. 2006, 250, 273-299.

[17] Q. L. Zhang, J.H. Liu, X.Z. Ren, H. Xu, Y. Huang, J. Z. Liu, L. N. Ji, J. Inorg. Biochem. 2003, 95, $194-$ 198

[18] G. M. Sheldrick, SHELXs-97, Program for the Solution of Crystal Structures, University of Göttingen, Göttingen (Germany) 1997. See also: G. M. Sheldrick, Acta Crystallogr. 1990, A46, $467-473$.

[19] G. M. Sheldrick, SHELXL-97, Program for the Refinement of Crystal Structures, University of Göttingen, Göttingen (Germany) 1997. See also: G. M. Sheldrick, Acta Crystallogr. 2008, A64, $112-122$. 